\title{
Flood, drought and the inter-annual variation to the number and size of ponds and small wetlands in an English lowland landscape over three years of weather extremes
}

\author{
Michael J. Jeffries
}

Received: 9 April 2015/Revised: 19 October 2015/Accepted: 20 October 2015/Published online: 30 October 2015

(C) The Author(s) 2015. This article is published with open access at Springerlink.com

\begin{abstract}
Ponds are biodiversity hotspots, but pond conservation is hampered by problems auditing these small, often temporary, habitats. Data on temporal changes to the number of ponds in response to weather variations are lacking. Annual and seasonal changes to the numbers and area of wetted ponds in a lowland farm in England were surveyed by field walks between November 2010 and November 2013. Plant communities were recorded to identify variations in pond type between land-uses. The study period coincided with severe drought up until April 2012 followed by record breaking precipitation. The wetted areas of ponds in wetlands and dune slacks showed the strongest relationship with rainfall over the preceding 4-6 months, whilst the areas of ponds in arable or pasture fields varied more with rainfall in the previous month. Ponds from different land-uses supported different plant communities and all types added to the overall total site biodiversity. Plant communities of ponds in arable fields benefitted from the extreme wet summer of 2012. The results show that the number and area of ponds varied significantly between years and seasons and that different pond types in different
\end{abstract}

Handling editor: Beat Oertli

M. J. Jeffries ( $₫)$

Department of Geography, Ellison Building, Northumbria University, Newcastle upon Tyne NE1 8ST, UK

e-mail: michael.jeffries@northumbria.ac.uk land-uses may vary in their response to extreme weather.

Keywords Ponds · Wetlands - Extreme weather · Land-use · Plants

\section{Introduction}

Ponds and small wetlands are ubiquitous throughout the Earth's terrestrial biomes from the equatorial tropics (Fasona \& Omojola, 2009) to Antarctica (Allende \& Mataloni, 2013), from pristine forests (e.g. the Amazon, Heckenberger et al., 2007), intensively managed agricultural lowlands (e.g. Taiwan, Chou et al., 2014) and urban landscapes (Hassall, 2014). Naturally occurring ponds are commonly augmented by anthropogenic ponds created for a specific purpose such as cattle watering in Romania (Hartel \& Von Wehrden, 2013), irrigation in Japan, (Usio et al., 2013), waste water treatment in Burkino Faso (Akponikpe et al., 2011) or accidently due to industry, e.g. subsidence ponds in north east England, Jeffries (2012). The importance of ponds as wildlife habitat went largely overlooked until the 1990s, especially smaller, temporary pools and wetlands, although there were occasional, prescient studies (Mozley, 1944). Researchers, land managers and policy advocates now recognise the importance of ponds. Ponds are disproportionately rich in overall 
species and rarities at the landscape scale compared to streams, rivers and lakes, (Williams et al., 2003; Davies et al., 2008). More recently their potential significance for ecosystem services has been highlighted, e.g. for controlling eutrophication or carbon sequestration (Downing, 2010; Céréghino et al., 2014; Gilbert et al., 2014) but uncertainty about the number and size of small ponds, especially those $<0.1 \mathrm{~km}^{2}$ in area, makes generalisations difficult (Downing et al., 2006).

Much of the work on ponds over the last 20 years was prompted by the loss of ponds from the agricultural lowlands of Europe and North America. Audits, primarily using historic maps, suggest that losses continued up until the 1990s (summarised Fairchild et al., 2013). Recent examples from the UK and USA followed the fate of ponds recorded on sequences of maps from the mid nineteenth century to the present day and showed more complex patterns, with periods of net loss, gains and the survival of individual ponds varying with origin and land-use (Jeffries, 2012; Fairchild et al., 2013). Note that ponds in very remote environments may also be under pressure from climate change, e.g. the High Arctic of Canada (Abnizova \& Young, 2010). Estimates of the numbers of ponds, primarily from intensively managed lowlands and using map records, have been widely reported (e.g. Wood et al., 2003; Williams et al., 2010; Jeffries, 2012). However, audits of the numbers and losses of ponds based on maps are always underestimates, in particular due to the minimum size thresholds below which features are not shown on maps, which will result in the omission of many small ponds. Historic maps can be revealing where the limits are recognised. For example Jeffries (2012) audited ponds shown on 1:10,000 Ordnance Survey maps of south east Northumberland, UK, from the 1860 s to the present day, showing that the total number of ponds had increased slightly but there had been marked turnover of individual ponds so that only 24 of the original 222 ponds were still depicted. These maps had a lower size threshold of $4 \mathrm{~m}$; smaller features would not be shown. In addition temporary ponds were typically not shown. The fundamental nature of temporary wetlands, the very characteristics that make them so biodiverse, such as their small size, cryptic and changeable nature, defies easy survey. Baldwin \& de Maynadier (2009) conclude that the ponds go unprotected because they are undetected.
Human impacts on landscape not only affect the total number of ponds but also impact upon their spatial distributions and size, resulting in changes from many, clustered ponds, to fewer, less clustered sites (Gibbs, 2000). The number of ponds in a landscape, their size and how these attributes change over time are core to both pond ecology and conservation. The number, density, and clustering of ponds all affect diversity patterns. For example $\alpha, \beta$ and $\gamma$ diversity generally increase with pond number and density in the landscape (e.g. Thiere et al., 2009; Bosiacka \& Pieńkowski, 2012) although communities can also become more similar if colonisation becomes more uniform.

Our growing awareness of the importance of ponds has prompted the use of remote sensing and modelling to quantify their number. These methods have great potential given the spatial scales and remote areas that can be covered but problems remain. Many remote sensing audits have minimum size thresholds for detection that are larger than most ponds and wetlands e.g. $>1 \mathrm{~km}^{2}$ (Lehner \& Döll, 2004), 0.4-1.2 ha (Pitt et al., 2012) and $0.5-1$ ha (Jones et al., 2009). Estimates of pond numbers and size also vary with the precise combinations of remote sensing and scales of maps or photographs (Abedini et al., 2006: Baldwin $\&$ de Maynadier, 2009; Gala \& Meleese, 2012) and are compounded by natural temporal change (Soti et al., 2010). Pond numbers can also be estimated from statistical models, even at a global scale. Using modelling Downing et al. (2006) and Downing (2010) suggested that both the numbers and areas of smaller ponds ("small ponds" refers to those of $<1000 \mathrm{~m}^{2}$, Downing, 2010) have been significantly under-estimated. Downing (2010, p. 13) estimated that natural ponds in this size range number $\sim 3.2 \times 10^{9}$, and have an area of 0.8 billion $\mathrm{km}^{2}$. However, the total land area of Earth is only 0.149 billion $\mathrm{km}^{2}$ and more recent modelling has challenged the suggestion that smaller lakes are so much more abundant (Seekell \& Pace, 2011; Verpoorter et al., 2014). The estimates from models, like those from remote sensing remain uncertain, especially for smaller ponds, but the general message that the numbers and area of small ponds are under-estimated holds good. The need for ground surveys is all too apparent.

Ground surveys result in marked increases to numbers of recorded ponds, particularly ponds in woodland (e.g. Calhoun et al., 2003; Pitt et al., 2012) 
and temporary wetlands. A powerful example of the value of field survey is the Countryside Survey of England, Scotland and Wales. Carried out in 1996 and 2007, the project used ground survey of $1 \mathrm{~km}^{2}$ sample areas of broad rural land-use types, the results from which are multiplied up in proportion to those overall land-use types to give national totals. The 1996 results were the first to show that seasonal ponds were widespread in the UK (Williams et al., 2010), which is more a record of our previous ignorance than of the novelty of temporary ponds. The 2007 survey estimated a total of 478,000 ponds, $70 \%$ of which were in the smallest size category between 25 and $400 \mathrm{~m}^{2}$.

The number of ponds through time is not only a problem for cartography but also a challenge for understanding the ecology of these habitats in the face of climate change to which they will be especially sensitive due to their small size (Rosset et al., 2010; Rosset \& Oertli, 2011; Ewald et al., 2012). Despite the recognition that small wetlands will be disproportionately vulnerable (Heino et al., 2009), they are usually missed out of global and national assessments of climate hazard (Brooks, 2009). The existing adaptations of temporary pond biodiversity do confer resistance and resilience to climatic variation, at least to drought (Lake, 2011), and temporary ponds support unique and rare taxa, e.g. branchiopods, which benefit from dry phases that prevent the establishment of many predators. A particular threat arises from novel extremes of rainfall, high or low, which wildlife have not previously encountered and against which their existing adaptations are ineffective (Jones, 2013). Extreme drought or rainfall have been shown to disrupt communities of plants (Johnson et al., 2004), invertebrates (Golladay et al., 1997; Jeffries, 2010) and amphibians (Wassens et al., 2013) associated with small wetlands. Pond numbers and size will vary with climate, both systematically with seasons but also in response to climate change and extreme events (Jones, 2013). Most studies of ponds and their wildlife are short term, usually surveys carried out in one year which do not capture temporal heterogeneity (Jeffries, 2005; Hassall et al., 2012). Given that the area, density and clustering of ponds in single year surveys all appear to affect species richness at the local and landscape-scale (e.g. Oertli et al., 2002: Thiere et al., 2009; Bosiacka \& Pieńkowski, 2012), the variability between years and changes associated with local climate variation are also likely to be important but remain under-researched.

Given their acknowledged importance for biodiversity and the growing evidence for their significant role in ecosystem services, estimating the numbers and extent of small ponds and wetlands and how these might vary between years, season and with local climate remains a challenge. This study was carried out to specifically address these questions by recording the number and area of ponds in an intensively managed lowland landscape in north east England over three years. The study addresses three main objectives: (1) quantifying the number of ponds in the landscape, especially of small ponds and their variation between land-uses in a managed, lowland farm, (2) quantifying the seasonal and annual changes to the number and extent of ponds and (3) characterising the sensitivity of ponds to regional climate variability and how this might vary between types of ponds within different land-uses. Changes to the number and area of ponds were related to regional seasonal and annual rainfall variation. Additionally during the study period, November 2010-November 2014, the region was subject to weather extremes, including both unusually wet and dry seasons. The plant communities of the ponds were recorded to characterise the pond types within broad land-uses and test how the number of different pond types might vary between years and land-use.

\section{Method}

\section{Survey site}

The survey was carried at Blakemoor Farm a mixed arable and livestock farm at the southern end of Druridge Bay on the Northumberland coast, (UK Ordnance Survey NZ 285 940, Fig. 1). The farm is typical of the south east lowlands of Northumberland, an area with a diverse mix of pond types (Jeffries, 2012). The farm and its broad land-uses have been unchanged since at least the 1860s, the date of oldest maps of the site. From 1950 onwards land subsidence over old coal seams has created large numbers of shallow mine subsidence ponds. The area surveyed was $1 \mathrm{~km}^{2}$ and the route walked was $12.5 \mathrm{~km}$ in length, zig zagging throughout the fields, so that all of 


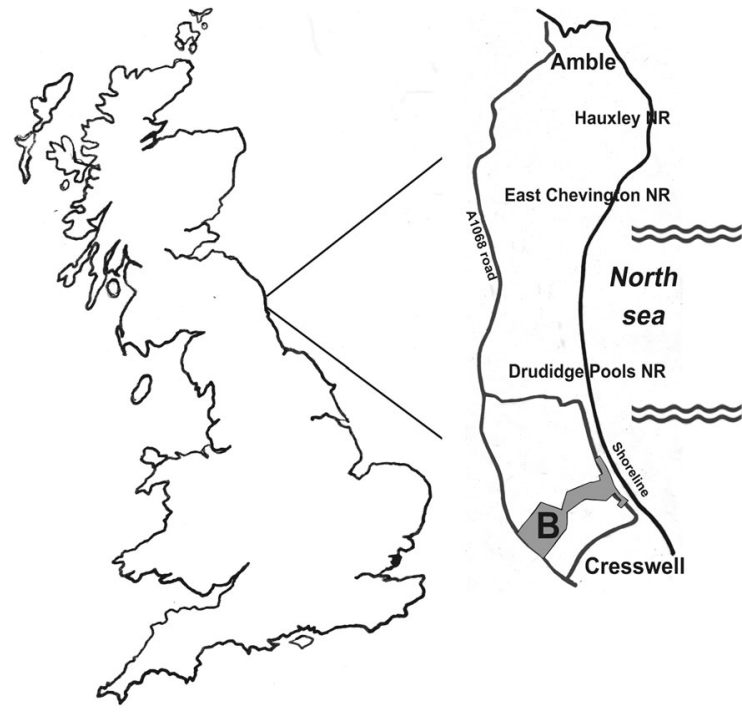

Fig. 1 The position of the Blakemoor Farm site and Druridge Bay in north east England, within the UK mainland. $B$ is the Blakemoor site, at the south end of Druridge Bay, shaded in grey. Nearby nature reserves are named and labelled " $N R$ ", along with the town of Amble and village of Cresswell

the landscape could be inspected to identify ponds down to $1 \mathrm{~m}^{2}$ in size.

Pond number and area

The number of ponds and small wetlands holding water was recorded by walking throughout the site, starting in November 2010. The farm was walked every few months: late November, January, March, late May and August from November 2010 to November 2013 inclusive. This resulted in fifteen walks during the study period; January 2012 was missed due to sustained bad weather. All ponds and wetlands were recorded including gateway pools and track puddles. The smallest size recorded were pools of $1 \mathrm{~m}^{2}$ and the largest was over $67,000 \mathrm{~m}^{2}$. In late May/early June and late November/early December of 2011 to 2013 the total area of standing water within each pond was recorded. For smaller ponds, i.e. less than $\sim 30 \mathrm{~m}$ along their longest axis, this was done by measuring the diameters or sides and treating them as ellipses or rectangles. Some ponds were irregular or broken up for example by tractor tramlines, in which case the measurements recorded the outer limits. The wetted areas of larger ponds were recorded on aerial images. Their dimensions such as diameter or edge length were measured and also distances to conspicuous features such as telegraph poles, gateways and trees so that their inundated extent could be drawn out on maps. The areas of these larger sites was then measured using Edina Digimap, (digimap.edina. ac.uk).

Ponds were initially grouped into four broad types based on their surrounding land-use. This was done because previous data suggested that regional pond types, characterised by their macrophyte plant communities, varied between different land-uses (Jeffries, 2012). The four categories were:

(1) Ponds in arable fields. These ponds lacked any adjacent natural or semi-natural vegetation, no buffer into the crops and were ploughed and planted with crops every year.

(2) Ponds in permanent pasture. Again these ponds lacked any adjacent natural or semi-natural vegetation or buffer into the managed pasture, and livestock (cattle or sheep) had complete access every year.

(3) Ponds in dune slacks. On the landward side of coastal dunes, on conspicuously sandy soil and subject to occasional brackish flooding from adjacent wetlands. Natural dune slack vegetation, unmanaged and with occasional cattle grazing.

(4) Ponds in amongst naturalistic wetland complexes and rough grassland creating distinct buffer zones. In a few cases livestock could potentially access the ponds, although the swampy surrounds largely prevented this. Hereafter they are referred to as 'natural wetlands', although they have developed on land that was managed 20-50 years ago.

Botanical survey

Macrophyte plants were surveyed (1) to characterise the ponds from the Blakemoor study site, examine differences in the vegetation of pond from the four different land-uses and if the plant communities supported the separation of ponds into the four groups based on land-use and (2) opportunistically following an extreme rainfall event in 2012 to record changes to flora in 2013 and 2014, in particular to ponds in arable fields. 


\section{Characterising the ponds using plant communities}

The plants from 55 of the 135 ponds found during the course of the surveys were recorded once during the summers of either 2012, 2013 and 2014. The 55 ponds were chosen to include examples of ponds from all four major land-use types, 10 from naturalistic wetlands, 18 from arable fields, 18 from pasture, and 9 from dune slacks. Following the National Pond Survey method all macrophytes within the outer pond margin were recorded (Pond Action, 1993). Identification followed Stace (1997) and Lansdown (2009) including microscopic examination where required e.g. Callitriche species or Epilobium seeds. The abundance of each taxon was recorded using the DOMIN scale, a ten category scale of $\%$ cover which is the standard survey method for the UK National Vegetation Survey including wetland vegetation (Rodwell, 1992).

\section{Responses of plant communities following an extreme rainfall event}

The record breaking rainfall from April 2012 onwards resulted in very high water levels and conspicuously luxuriant growth of macrophytes especially in ponds in the arable fields. This event was used opportunistically to examine how the unusually verdant plant communities fared in subsequent years. From the original 55 ponds surveyed in 2012, a subset of 20 ponds were re-surveyed in the summers of 2013 and 2014. The surveys were confined to ponds from either the natural wetlands $(N=6)$ or arable fields $(N=14)$ because of the particular impact of the 2012 inundation on the arable sites, to compare changes to the species richness and cover of plants in these arable ponds if there was a return to normal summer dry phases in 2013 and 2014.

\section{Rainfall data}

The regional climate of the south east Northumberland plain, where Blakemoor is situated, is relatively cool compared to southern England, but surprisingly dry due to rain-shadow from hills to the west and north (Lunn, 2004). Total monthly rainfall data from the nearest British Meteorological Office weather station at Boulmer (Ordnance Survey NU 253 142) were used to examine changes to the number and areas of ponds holding water during the survey period. Boulmer weather station is a coastal site $21 \mathrm{~km}$ north of Blakemoor with mean monthly rainfall during the survey period of $60.5 \mathrm{~mm}$, and a mean temperature of $9.3^{\circ} \mathrm{C}$. Regional climate is broadly stable at the $50 \mathrm{~km}$ scale. Rainfall at Boulmer during the study period was highly correlated with Newcastle Weather Centre and Albermarle weather stations, both $\sim 50 \mathrm{~km}$ south of the study site $(r=0.882$ and 0.828 , respectively, $P<0.001)$ suggesting that Boulmer provides representative rainfall for the region of Blakemoor Farm.

The period of this study coincided with striking climate extremes in the UK, including in the study region. The general pattern was one of drought from 2010 to March 2012, extreme rainfall from April to December 2012, followed by a largely average 2103 except for a July drought and heatwave (Met Office, 2015). Table 1 provides a summary.

\section{Analyses}

The relationships between total wetted areas of the ponds from different land-uses and regional rainfall were characterised using linear regression, using wetted area measures first recorded in November 2010 and thereafter in May and November of the survey years, resulting in seven sets of measures in total. Total wetted areas for each pond type were regressed against the rolling means of rainfall from a range of preceding months, $1-6,8$ and 12 , to identify the strongest relationships. Rolling means were used primarily to explore how rainfall over different time scales might affect ponds in different land-uses.

The plant communities of the 55 ponds surveyed to identify pond types and variations between ponds from different land-uses were characterised using TWINSPAN and DECORANA, with ANOSIM to test differences between groups of ponds. Differences in the numbers of taxa between pond types were tested using one-way ANOVA. Differences in the numbers of taxa from the 20 ponds recorded in 2012 and resurveyed in 2013 and 2014 were tested by two-way ANOVA comparing year and pond type (natural or arable). Changes to the DOMIN scale cover of plants from the 20 ponds over these 3 years were compared using the Kruskal-Wallis test.

Multivariate statistics were carried out using CAP 3.1, all other analyses using SPSS 22. 
Table 1 Summary of UK and Blakemoor region extreme weather events over the study period (summarised from Met Office, 2015)

\begin{tabular}{|c|c|c|}
\hline Time Period & General description of national and regional weather & Blakemoor region rainfall and temperature. \\
\hline $\begin{array}{l}2009 \text { to March } \\
2012\end{array}$ & $\begin{array}{l}\text { One of the most significant droughts in England for } 100 \text { years, } \\
\text { with marked rainfall deficiency. The spring of } 2011 \text { was } \\
\text { particularly warm and dry, with } 2011 \text { as a whole the second } \\
\text { warmest year since } 1910\end{array}$ & $\begin{array}{l}\text { From April } 2010 \text { to March } 2012 \text { the rainfall in } \\
\text { the Blakemoor Farm region was } 85-95 \% \text { the } \\
\text { long-term average. Total April rainfall at } \\
\text { Boulmer during this period was } 14.5 \mathrm{~mm} \text {, } \\
\text { mean monthly rainfall June to August was } \\
78.1 \mathrm{~mm}\end{array}$ \\
\hline $\begin{array}{l}\text { April } 2012 \text { to } \\
\text { December } \\
2012\end{array}$ & $\begin{array}{l}\text { A sudden change at the start of April heralded exceptional } \\
\text { rainfall leading to the wettest year in England since records } \\
\text { began in } 1766 \text {. The exceptionally wet weather persisted } \\
\text { throughout the summer until December. The region including } \\
\text { Blakemoor was subject to particular extreme rainfall on 28th } \\
\text { June, "Thunder Thursday" }\end{array}$ & $\begin{array}{l}\text { Rainfall in the Blakemoor region from April to } \\
\text { July } 2012 \text { was } 175-200 \% \text { of the long-term } \\
\text { average. Total April rainfall at Boulmer was } \\
117.8 \mathrm{~mm} \text {. Mean monthly rainfall June to } \\
\text { August was } 103.8 \mathrm{~mm}\end{array}$ \\
\hline 2013 & $\begin{array}{l}\text { Rainfall and temperature were near average for the year overall, } \\
\text { however a unusually long hot, dry spell occupied throughout } \\
\text { July, resulting in the third warmest July since } 1910\end{array}$ & $\begin{array}{l}\text { Between } 3 \text { rd and } 21 \text { st July regional weather } \\
\text { stations reported only } 0.3-0.6 \mathrm{~mm} \text { rain. July } \\
\text { temperatures were between } 0.5-6.0^{\circ} \mathrm{C} \text { higher } \\
\text { than the regional average for } 21 \text { days. Total } \\
\text { April rainfall at Boulmer was } 16.6 \mathrm{~mm} \text {, mean } \\
\text { monthly rainfall June to August was } 49.2 \mathrm{~mm} \text {. }\end{array}$ \\
\hline
\end{tabular}

\section{Results}

The number and area of ponds holding water and relationship to variations in rainfall

The majority of ponds on Blakemoor Farm are small, $<1000 \mathrm{~m}^{2}$, and temporary. Over the course of the 3 years 135 wetlands, ponds and pools were identified, of which 86 were recorded as holding water more than once. The number of ponds varied between a maximum of 105 within the $1 \mathrm{~km}$ survey area in the autumn of 2012 and a minimum of 12 in August 2011, with an average of 53.4 ponds across the 15 walks. The maximum number of ponds in each land-use were 55 in pasture (including 9 small but recurrent gateways pools), 46 in arable fields, 35 in natural wetlands and 9 dune slacks. All the natural and dune ponds were wetted for at least part of each year, compared to only 22 of the pasture ponds and 17 in the arable fields.

The number and areas of wetted ponds varied markedly with rainfall. The total number of ponds holding water was strongly correlated with mean rainfall over the preceding months, the 6-month rolling average giving the strongest correlation (Fig. 2, Pearson's correlation, $r=0.734, P<0.01$ ). Total wetted areas of the four pond types recorded at the May and November site visits varied from a minimum of $43,000 \mathrm{~m}^{2}$ in the early summer of 2011 to over $115,000 \mathrm{~m}^{2}$ in the late autumn of 2012 (Fig. 3). The impacts of the extreme weather are obvious, with the total wetted areas lowest in the summers of 2011 and 2013 during drought and heatwave, but high in the summer of 2012 and highest in the autumn of 2012 as record breaking rainfall, up to $200 \%$ of the long-term monthly averages, prevented routine summer drying and inundated new sites. The variation is particularly striking in the arable and pasture field ponds, the total area varying between 2900 to $25,300 \mathrm{~m}^{2}$ and $700 \mathrm{~m}^{2}$ to just under $10,000 \mathrm{~m}^{2}$, respectively. Of the recurrent 17 ponds in arable fields that filled every year only one very large pond did not dry out in the summer. Similarly only one of the pasture ponds did not dry out at some stage. The size distribution of ponds also varied with rainfall (Fig. 4) throughout the survey period of November 2010 to November 2013. During the wettest season, when pond numbers were at their highest in the autumn of 2012, ponds with an area of between 100 and $1000 \mathrm{~m}^{2}$ dominated. However, when the number of ponds was at its lowest in the summer of 2011 the smallest ponds up to $10 \mathrm{~m}^{2}$ were the most frequent.

The total wetted areas of ponds from all four landuses showed strong positive relationships to rainfall over the preceding months although the best models 
Fig. 2 The number of ponds holding water on each of the fifteen site visits, plotted against the mean monthly rainfall recorded at Boulmer for the preceding 6 months. The survey months and years are shown

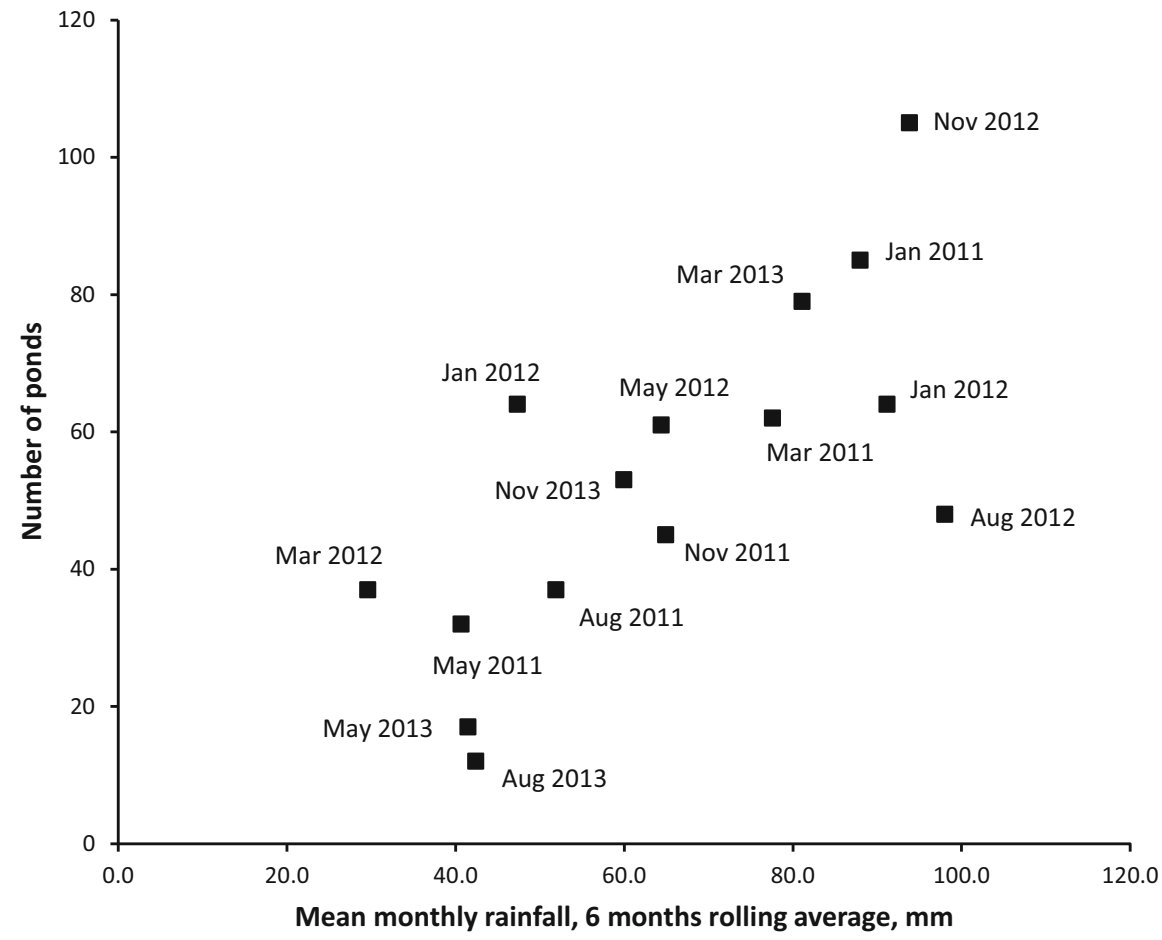

Fig. 3 The area of each of the four main pond types in autumn (Late November/ early December) and summer (Late May/early June) between 2010 and 2013. Ponds in the four landuse types are differentiated black-filled square dune slack, dark grey-filled square pasture, grey-filled square arable and square natural wetlands. The first three sample occasions fell within a period of rainfall deficiency lasting from 2009 to March 2012, including an unusually warm year, 2011. The two dates in 2012 were within the period April to December, the wettest year on record in England since 1766. The summer of 2013 was dominated by a heatwave

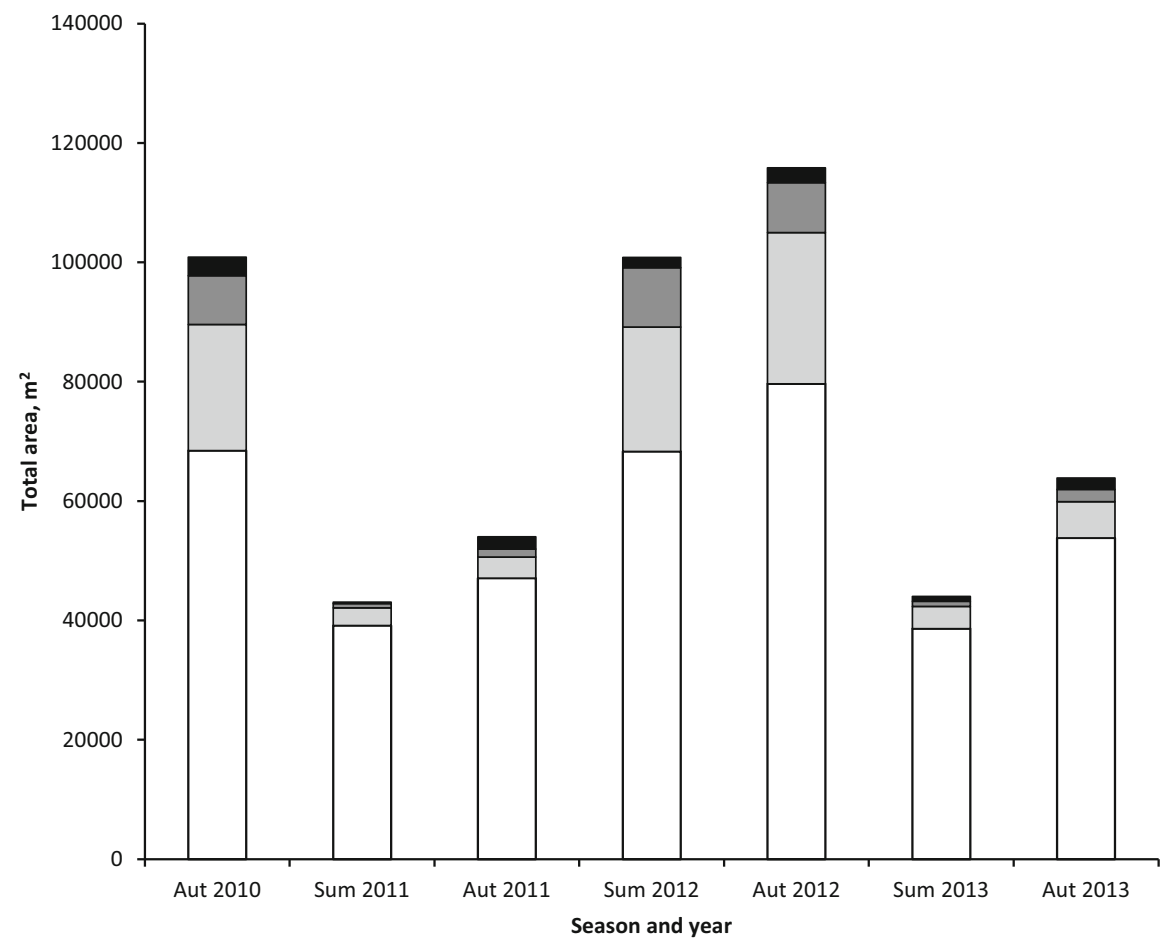

varied between land-use. For the ponds in dunes and natural wetlands, the rainfall during the preceding 4-7 months all gave significant relationships
$(P<0.05)$ with high $r^{2}$ values $(0.6$ to $0.8+)$, the rainfall over 5 and 4 months giving the highest $r^{2}$ for dune and natural wetland ponds, 0.879 and 0.874 , 
Fig. 4 Variation in the frequency of individual pond sizes between the site visits with the smallest number (late May-June 2011) and the largest number of ponds (November 2012). The histogram shows the numbers of ponds in five wetted area categories for May/early June 2011, rectangle and November 2012, filled rectangle

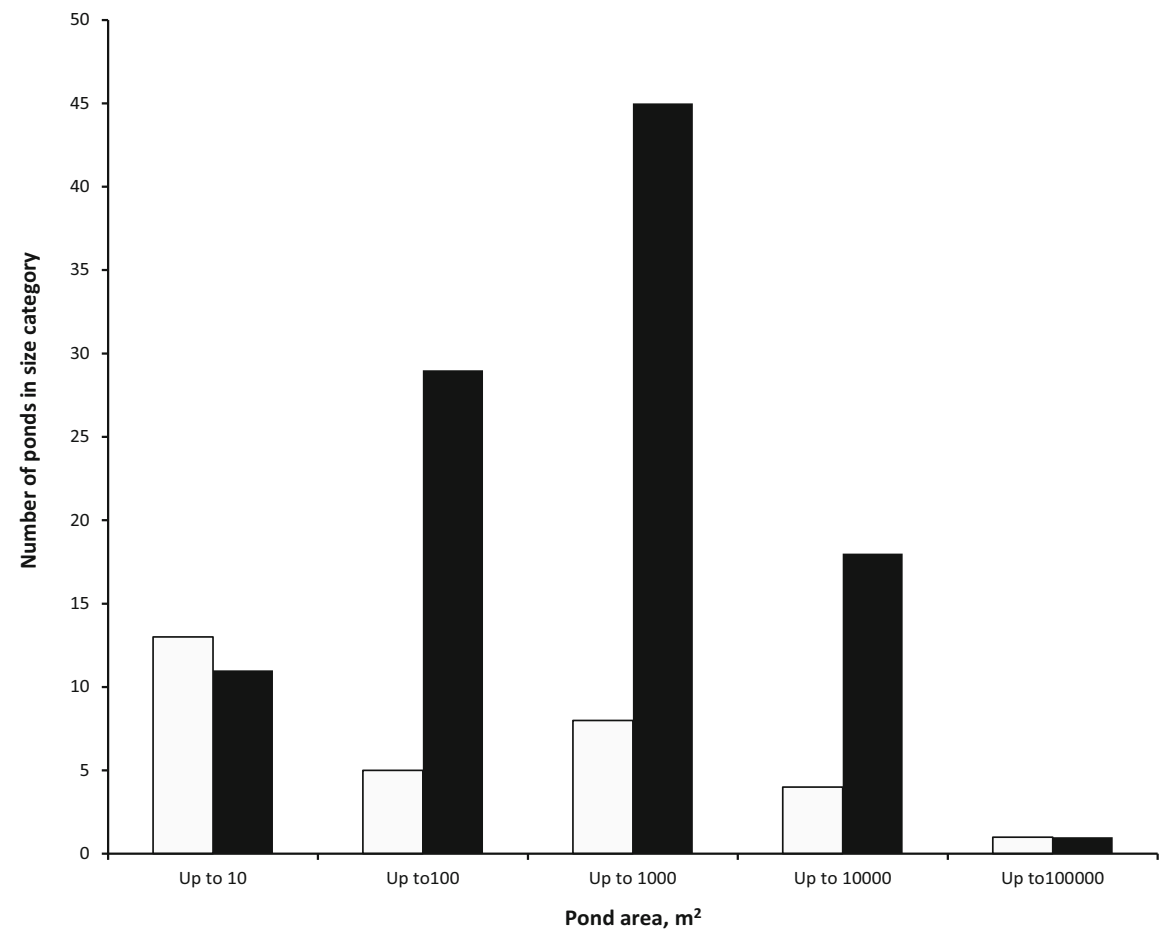

respectively (Table 2). For the ponds in arable and pasture fields, the wetted areas showed the strongest relationships to rainfall for the month immediately preceding the site visits, giving $r^{2}$ values of 0.807 and 0.798 , respectively (Table 2). Local rainfall is the key to the numbers and sizes of pond at Blakemoor.
Botanical characterisation of the ponds

The macrophyte plant data were used to characterise the 55 ponds surveyed, to test differences in species richness between ponds from the four different landuses and to use the plants to classify the ponds to test if

Table 2 Relationship between total wetted area of the four pond types and regional rainfall

\begin{tabular}{lll}
\hline Regression equations & & \\
\hline $\begin{array}{l}\text { Pond type } \\
\text { Wetland }\end{array}$ & Wet area, $\mathrm{m}^{2}=20114.5+507.7$ (mean rainfall previous 4 months) & $r^{2}=0.874, P<0.01$ \\
& Wet area, $\mathrm{m}^{2}=36451.1+213.1$ (rainfall during the survey month) & $r^{2}=0.704, P<0.05$ \\
& Wet area, $\mathrm{m}^{2}=12369.2+670.6$ (mean rainfall previous 8 months) & $r^{2}=0.363, \mathrm{~ns}$ \\
Dune slack & Wet area, $\mathrm{m}^{2}=-562.4+34.3$ (mean rainfall previous 5 months) & $r^{2}=0.879, P<0.01$ \\
& Wet area, $\mathrm{m}^{2}=693.9+11.4$ (rainfall during the survey month) & $r^{2}=0.497, P<0.05$ \\
Arable field & Wet area, $\mathrm{m}^{2}=248.9+23.0$ (mean rainfall previous 8 months) & $r^{2}=-0.021, \mathrm{~ns}$ \\
& Wet area, $\mathrm{m}^{2}=-1032.4+58.9$ (rainfall during the survey month) & $r^{2}=0.807, P<0.01$ \\
Pasture field & Wet area, $\mathrm{m}^{2}=-9414.4+298.6$ (mean rainfall previous 4 months) & $r^{2}=0.755, P<0.01$ \\
& Wet area, $\mathrm{m}^{2}=-16839+438.1$ (mean rainfall previous 8 months) & $r^{2}=0.417, \mathrm{~ns}$ \\
& Wet area, $\mathrm{m}^{2}=-1083.4+138.9$ (rainfall during the survey month) & $r^{2}=0.788, P<0.01$ \\
& Wet area, $\mathrm{m}^{2}=-4158.9+120.9$ (mean rainfall previous 4 months) & $r^{2}=0.721, P<0.01$ \\
& Wet area, $\mathrm{m}^{2}=-4446.4+136.1$ (mean rainfall previous 8 months) & $r^{2}=0.150, \mathrm{~ns}$
\end{tabular}

Regressions were run against a range of rainfall means. The table shows the results with the highest adjusted $r^{2}$ values and, for comparison, the outcomes for a range of other periods 
the resulting groups matched the broad scale division into four types based on land-use. The DECORANA and TWINSPAN analyses suggested the ponds clustered into four groups (Fig. 5), comprising sites in dune slacks (plus a few others with brackish intrusion), ponds in arable fields, a third group comprising ponds in pasture or natural wetland (ponds from the two landuses are rather separate within the overall group, see Fig. 5) and a fourth set of small pools that recurred in gateway entrances to fields. The four TWINSPAN groups are all significantly different to each other, ANOSIM, $P<0.001$ : Table 3 gives group characteristics, e.g. plants and patterns of drying. Therefore, the clustering of ponds based on the plant data do not exactly match the four groups based on land-use, primarily because of the separation out of the gateway pools. Subsequent results and discussion retain the four original groups based on land-use but with a fifth group comprising the gateway ponds added.

The numbers of taxa varied markedly between these pond types (Fig. 6. Note that the data from pasture and natural wetland ponds which grouped together in the TWINSPAN analysis are plotted separately, giving five pond types in the figure). The total numbers of taxa were significantly higher in the natural wetland and dune ponds. Taxa were also separated into three broad types: emergent, aquatic and terrestrial types based on the plant list in Pond Action (1993). Emergent species were significantly higher in the natural wetland ponds, whilst terrestrial species were more abundant in the arable field and dune ponds. The small gateways ponds supported significantly lower total and emergent taxa. There were few aquatic submerged or floating species in any of the pond types, although they were most frequent in the natural wetland ponds.

Botanical variation between the summers of 2012 to 2014

The taxa richness in the 20 ponds re-surveyed across the three summers was compared, again for both the total taxa and emergent, aquatic and terrestrial taxa separately: Fig. 7 summarises the numbers of taxa in the 14 arable versus the 6 natural wetland ponds for each of 2012, 2013 and 2014. ANOVA showed no significant differences in numbers of taxa between the 3 years or in the interaction between years and pond type. Emergent and aquatic species richness were significantly higher in the natural ponds, whilst the number of terrestrial species was higher in the arable field ponds (ANOVA, $P<0.001$ in all cases).
Fig. 5 DECORANA ordination of 55 ponds at Blackmoor based on summer plant communities; axes 1 and 2 represent 55 and $22 \%$ of the variation, respectively. Group 1 filled diamond, dune slacks and diamond pasture or natural wetland ponds with brackish intrusion. Group 2 filled square and square, the filled squares are ponds in amongst wetland complexes and rough grass, the unfilled squares from permanent pasture. Group 3 filled triangle, ponds in arable fields. Group 4 filled circle, small pools in gateways

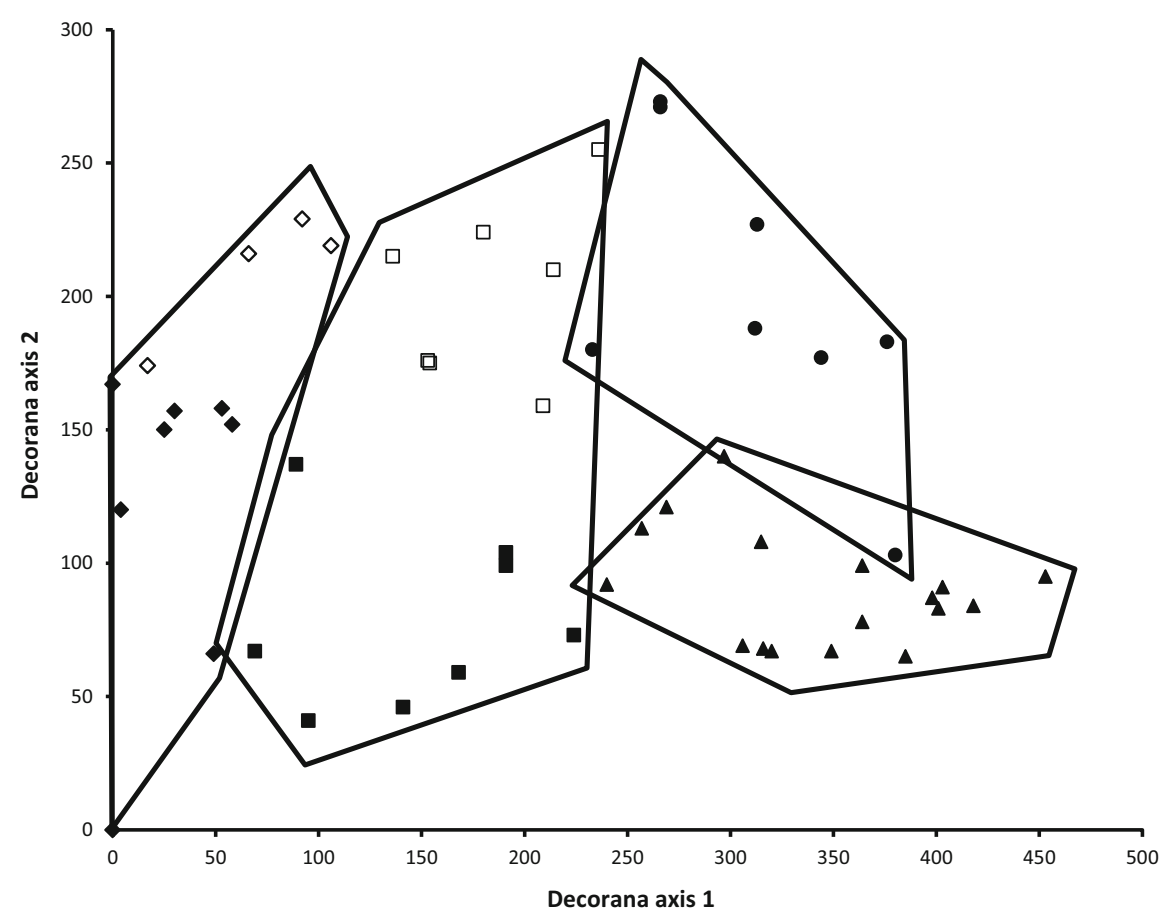


Table 3 The four main groups of ponds at the Blakemoor Farm site based on summer botanical survey of 55 ponds

\begin{tabular}{|c|c|}
\hline $\begin{array}{l}\text { Pond } \\
\text { group }\end{array}$ & Characteristic vegetation \\
\hline 1 & $\begin{array}{l}\text { Ponds mostly in dune slacks plus three from further inland with some brackish intrusion. Dominant plants Agrostis } \\
\text { stolonifera, Potentilla anserine L., Eleocharis palustris and some brackish indicators e.g. Triglochin maritimum L. or } \\
\text { tolerant Ranunculus scleratatus L.. The dune slacks dry up in most summers }\end{array}$ \\
\hline 2 & $\begin{array}{l}\text { A group combining ponds in amongst permanent pasture with ponds surrounded by extensive natural vegetation in } \\
\text { amongst wetland. In Fig. } 5 \text { the pasture ponds and those in wetlands are differentiated within the overall group. In the } \\
\text { ponds from permanent pasture Alopecurus geniculatus, Eleocharis palustris, Glyceria fluitans (L.) R. Br. dominate } \\
\text { with few other species. The ponds in amongst wetland complexes have these species along with larger emergents such } \\
\text { as Juncus articulatus L., Sparganium erectum and Typha latifolia L. and a diverse understorey of herbs. The majority } \\
\text { of ponds in pasture dry in the summer but the ponds in the wetlands do not }\end{array}$ \\
\hline 3 & $\begin{array}{l}\text { Ponds from arable fields with Atriplex postrata, Matricaria matricarioides, Polygonum aviculare and Tripleurospermum } \\
\text { inodorum (L.) Sch. Bip.. Communities akin to UK National Vegetation types OV18 and OV28-31 which are found in } \\
\text { disturbed, occasionally inundated ground (Rodwell, 2000). These ponds dry in most summers and the majority are } \\
\text { ploughed over }\end{array}$ \\
\hline 4 & $\begin{array}{l}\text { A group of small but recurrent pools in gateways of pasture fields with very few species. Matricaria matricarioides, } \\
\text { Alopecurus geniculatus, Lolium perenne L. common. They dry most summers }\end{array}$ \\
\hline
\end{tabular}

The groups are characterised by TWINSPAN and DECORANA

The mean DOMIN scores for widespread taxa (i.e. taxa found in $6+$ ponds in 2012 with at least one pond with DOMIN cover of 4+, 4-10\%) characteristic of either the arable field or natural wetland ponds are given in Table 4. There was no significance differences between the three years in scores for the species associated with the natural wetlands. In the arable field ponds, DOMIN scores were significantly higher for Capsella bursa-pastoris (L.) Medik, Matricaria matricarioides DC., Atriplex prostrata Boucher ex DC., and Polygonum aviculare L. in 2012 whilst Sonchus asper (L.) Hill became more abundant in 2014. Capsella bursa-pastoris was the only widespread species in 2012 that was lost in subsequent years.

The plant communities in the twenty ponds surveyed in 2012 and again in 2013 and 2014 to examine changes to vegetation after the 2012 extreme weather event were compared using DECORANA (Fig. 8). The ordination separated out the ponds in the arable fields versus those amongst natural wetlands into two distinct groups. However, within both groups, the positions of most ponds in each of the three different summers overlap; there were no substantial differences in species composition between years with the exception of four distinct outliers from the arable field pond in 2014 (circled in Fig. 8). In 2014, these four ponds were extensively covered in the crop species barley and had lost their pond flora. In most years, crop species die as the ponds retain open water into the late spring but in 2014 these ponds had dried up much earlier and the crops flourished.

\section{Discussion}

The objectives of the survey were primarily to quantify the number of ponds in a farmed lowland landscape, how their number and area changed over 3 years in response to rainfall and how these changes might vary between ponds in different land-uses. In addition the record breaking rainfall of 2012 was used opportunistically to record the changes to pond vegetation that had flourished in the arable field ponds in the aftermath of the extreme weather.

The number of ponds throughout the farm varied between a maximum of 105 within the $1 \mathrm{~km}$ survey area in the autumn of 2012 and a minimum of 12 in August 2011, with an average of 53.4 ponds across the 15 walks. The number of ponds shown on any large scale map of the farm over the same area is just 11, of which 10 were relatively large ponds in the natural wetland complexes usually $>1000 \mathrm{~m}^{2}$ but including one large arable field subsidence pond. Ground survey therefore revealed many more ponds than shown on maps, in line with the evidence from other audits incorporating ground truthing (Calhoun et al., 2003; 

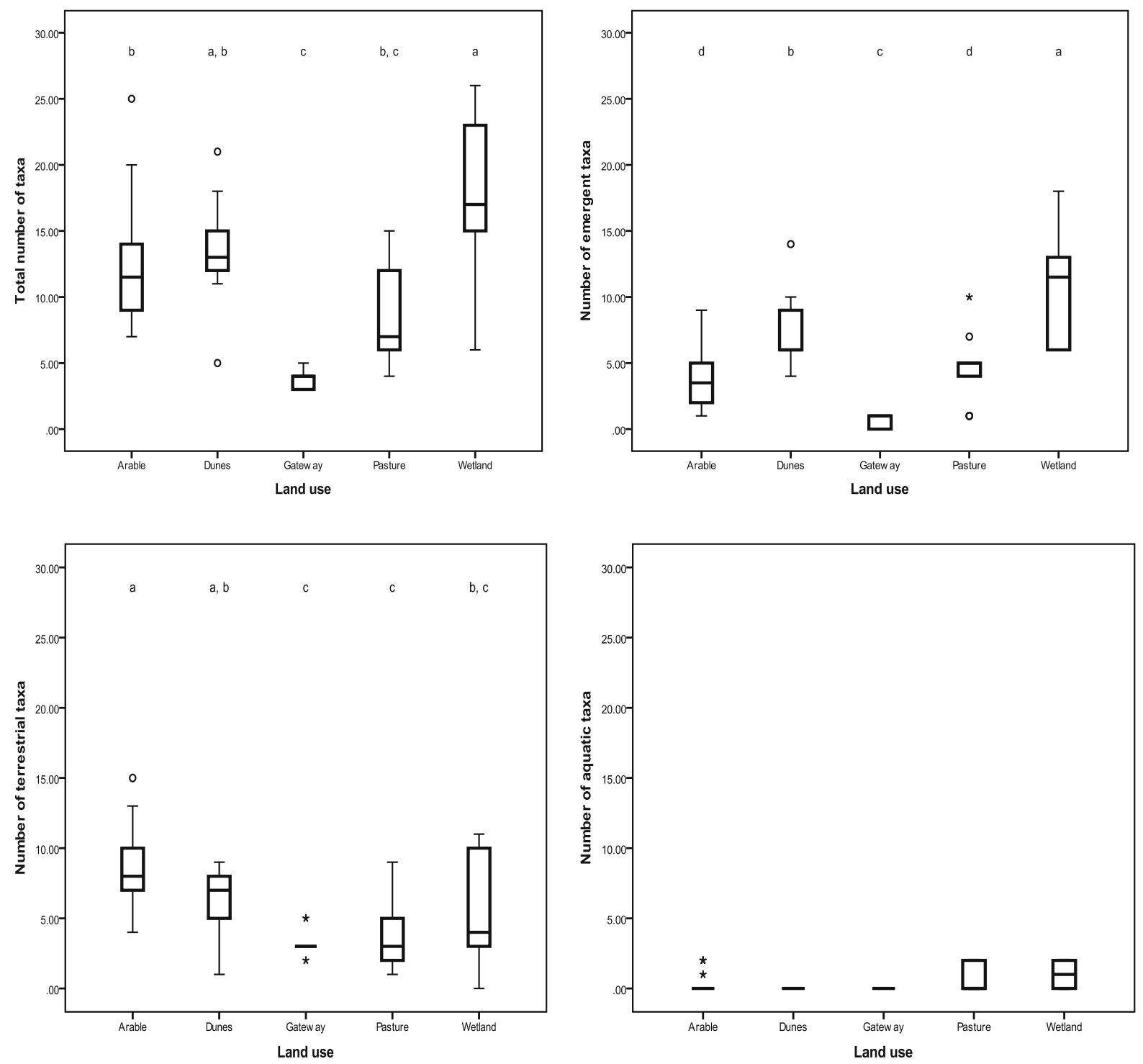

Fig. 6 Box and whisker plots of plant species richness from the ponds in arable fields, dune slacks, small gateway ponds in pasture, pasture fields and natural wetlands. The differentiation of the small gateway ponds from the others in pasture is because

they were identified as a distinct group with a characteristic but limited flora. Plants are separated into aquatics, emergent and terrestrial taxa based on lists in Pond Action (1993)

Williams et al., 2010; Pitt et al., 2012). The density of ponds is very high compared to published estimates from lowland England, which are largely based on map surveys (e.g. Wood et al., 2003). This is partly the result of land subsidence at Blakemoor over the old coal seams, as well as the result of the detailed ground survey. The subsidence wetlands of south East Northumberland are characteristic of the regional landscape, unusual at a national scale and perhaps

internationally too. The larger subsidence ponds are known to support distinctive plant communities and may be less vulnerable to the arrival of invasives such as Crassula helmsii (Kirk) Cockayne because the ponds tend to be out of sight and on private land, compared to heavily visited sites on nature reserves (Jeffries, 2012).

Ponds in different land-uses supported distinct plant communities, all of them adding to the landscape 

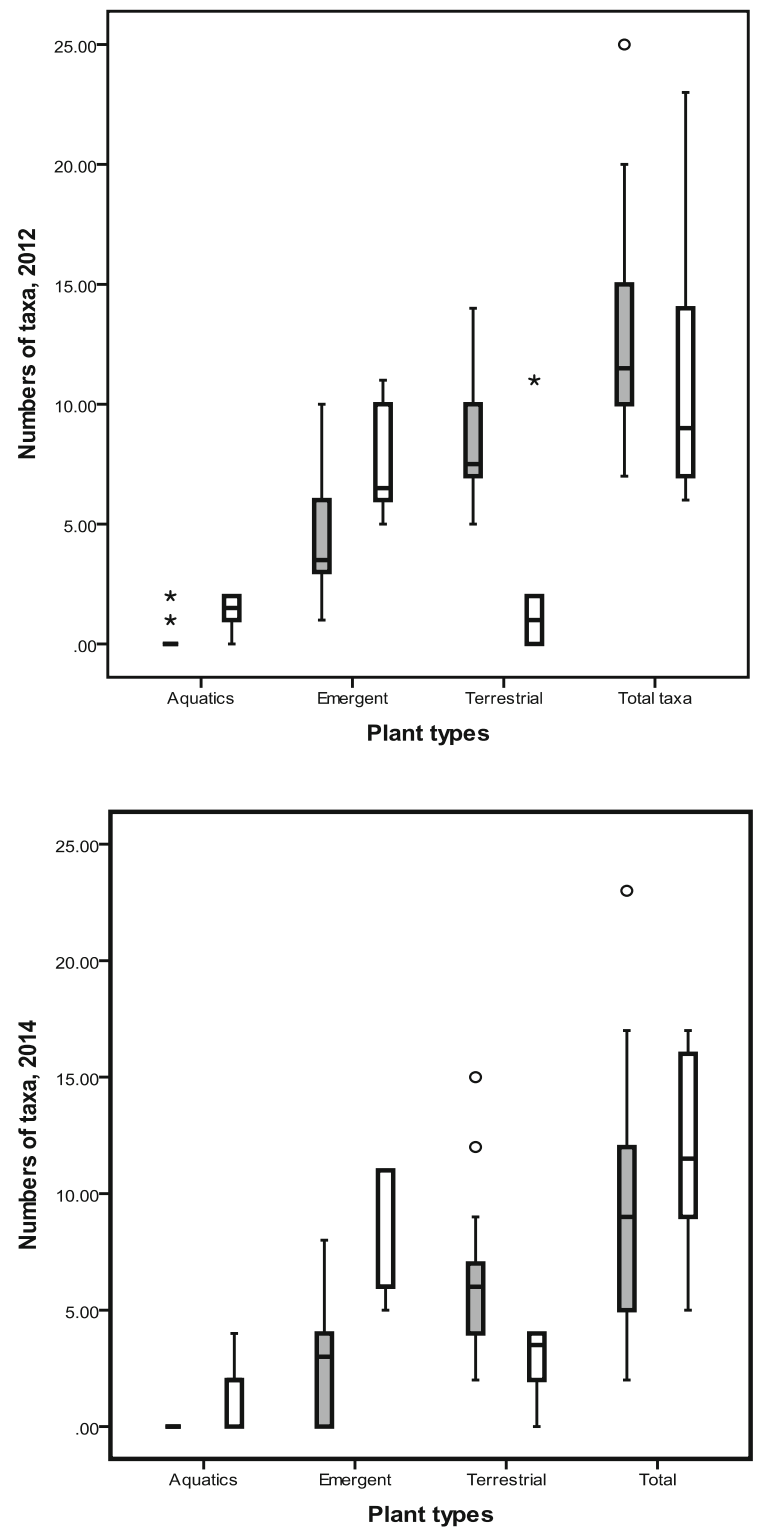

Fig. 7 Box and whisker plots of the numbers of plant taxa from the 20 arable field and natural wetland ponds re-surveyed in 2102, 2013 and 2014. Grey filled rectangle arable field ponds,

biodiversity. Most of the Blakemoor ponds were small, temporary sites but recent evidence has shown that these can be home to diverse animal and plant communities, including very small sites, characterised by Williams (1987) as micro-habitats. For example ruts, track pools and livestock troughs can support rare taxa or are the preferred habitat of some amphibians (Garcia-Gonzalez \& Garcia-Vazquez, 2011; Armitage et al., 2012; Hartel \& Von Wehrden, 2013). Pools

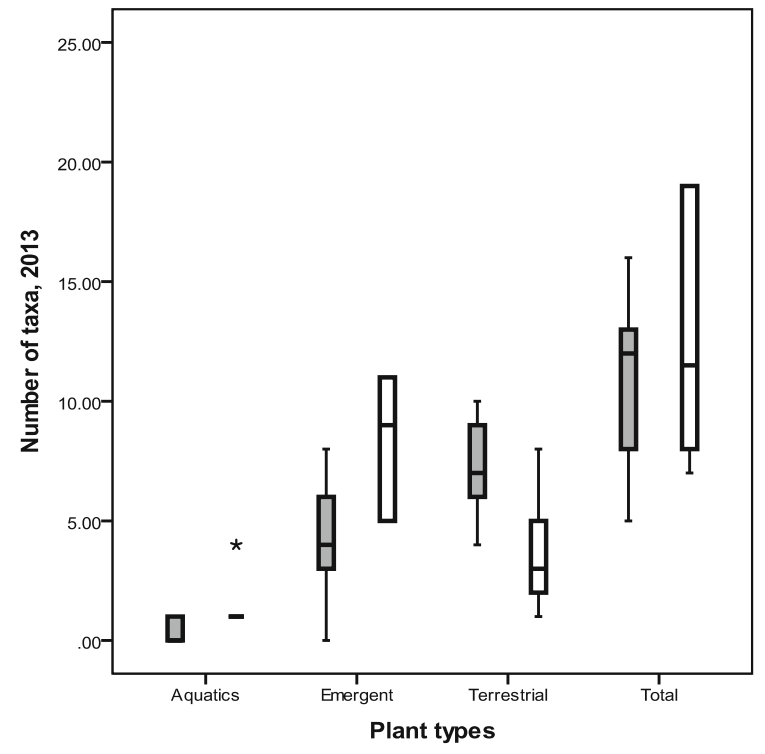

rectangle natural wetland ponds. Plants are separated into aquatics, emergent and terrestrial taxa based on lists in Pond Action (1993)

in arable fields are another distinct but overlooked habitat, with characteristic communities of plants (Lukás et al., 2013) or terrestrial Carabidae and Staphylinidae beetles (Lott, 2001; Brose, 2003). Although the plant communities were not the primary focus of this study it is notable that different communities were associated with different land-uses and that ponds from all four land-uses add to the overall diversity of taxa and communities. The natural 
Table 4 Mean DOMIN scores of widespread species from the twenty ponds surveyed in summer 2012 and re-surveyed in 2013 and 2014

\begin{tabular}{|c|c|c|c|c|c|c|}
\hline & \multicolumn{3}{|c|}{ Natural wetlands } & \multicolumn{3}{|c|}{ Arable field ponds } \\
\hline & 2012 & 2013 & 2014 & 2012 & 2013 & 2014 \\
\hline \multicolumn{7}{|l|}{ Taxa typical of wetland ponds } \\
\hline Agrostis stolonifera & 3.0 & 4.8 & 3.0 & 0.4 & 0.4 & 0.6 \\
\hline Alopecurus geniculatus & 4.5 & 4.5 & 2.6 & 2.5 & 3.6 & 2.9 \\
\hline Eleocharis palustris & 3.7 & 5.2 & 5.0 & 0.2 & 0.2 & 0.4 \\
\hline Glyceria fluitans & 1.2 & 2.0 & 1.7 & 0.2 & 1.1 & 0.1 \\
\hline Juncus bufonius agg. sensu lato $L$. & 1.2 & 0.7 & 1.0 & 1.2 & 1.6 & 2.9 \\
\hline Ranunculus scleratatus & 0.7 & 0.5 & 0.7 & 0.6 & 0.7 & 0.5 \\
\hline Rorippa palustris & 1.3 & 1.2 & 1.5 & 0.4 & 1.0 & 0.4 \\
\hline \multicolumn{7}{|l|}{ Taxa typical of arable field ponds } \\
\hline Capsella bursa-pastoris & 0 & 0 & 0 & 1.8 & $0 * * *$ & 0 \\
\hline Gnaphalium uliginosum L. & 0.3 & 0 & 1.2 & 1.2 & 0.5 & 3.0 \\
\hline Matricaria matricarioides & 0.5 & 0.3 & 0.7 & 4.2 & $3.4 * * *$ & 3.1 \\
\hline Atriplex prostrata & 0 & 0 & 0 & 2.1 & $0.5^{* * *}$ & 1.0 \\
\hline Роа аппиа $\mathrm{L}$. & 0.7 & 0.7 & 0 & 3.0 & 4.4 & 5.7 \\
\hline Polygonum aviculare & 0.5 & 0 & 0 & 2.6 & $1.9 * * *$ & 0.3 \\
\hline Sonchus asper & 0 & 0 & 0 & 0.2 & $0 * *$ & 1.7 \\
\hline Tripleurospermum inodorum & 0.3 & 0 & 0.2 & 1.7 & 1.6 & 5.1 \\
\hline
\end{tabular}

DOMIN scores are a 1-10 scale representing different $\%$ cover, widely used for vegetation in the UK.: $10=91-100 \%, 9=76-90 \%$, $8=51-75 \%, 7=34-50 \%, 6=26-33 \%, 5=11-25 \%, 4=4-10 \%, 3=<4 \%$, many individuals, $2=<4 \%$ several individuals, $1=<4 \%$ few individuals (Rodwell, 1992). Significant differences between years (Kruskal-Wallis) are shown by $* * P<0.05, * * *$ $P<0.001$

wetland and dune slack ponds supported plant communities typical of shallow ponds throughout the UK, e.g. National Vegetation Classification swamp communities such as S19 Eleocharis palustris (L.) Roem. \& Schult., and S14 Sparganium erectum L. swamp (Rodwell, 1995). The amphibious grass communities of the pasture ponds, e.g. NVC MG13 Agrostis stolonifera L.-Alopecurus geniculatus L. grassland and the disturbed ground plants of the arable fields, e.g. OV 29 Alopecurus geniculatus-Rorippa palustris (L.) Besser community (Rodwell, 1992, 2000), were not found in the natural wetland and slack ponds. Even the very small gateways ponds had a distinct, if species poor, flora. Of the 82 plant taxa recorded 11 and 3 , respectively, were only found in the arable or pasture ponds, along with 4 out of $16 \mathrm{NVC}$ communities only found in arable field ponds. The highest numbers of taxa were found in the natural wetland and dune ponds, in particular higher numbers of emergent species. The species of arable ponds were predominantly terrestrial taxa associated with disturbed, inundated ground. This reinforces the results from Armitage et al. (2012) and Hartel \& Von Wehrden (2013) highlighting the value of these overlooked sites at the landscape scale. Pond plant communities are known to vary with land-use, e.g. increased biodiversity in ponds surrounded by more wetland (Williams et al., 2008) or private land as a refuge from invasives spread by human visitors (Jeffries, 2012). Precise causal links often remain unidentified although damage from livestock trampling, grazing and dunging is known to degrade pond plant communities (Declerck et al., 2006; Croel \& Kneitel, 2011) and ploughing of shallow ponds in arable fields is likely to be just as damaging.

The number of wetted ponds and their areas varied markedly between years and seasons, the variations strongly related to regional rainfall. These variations are a challenge to conventional audits of pond densities and to studies using pond area as an 


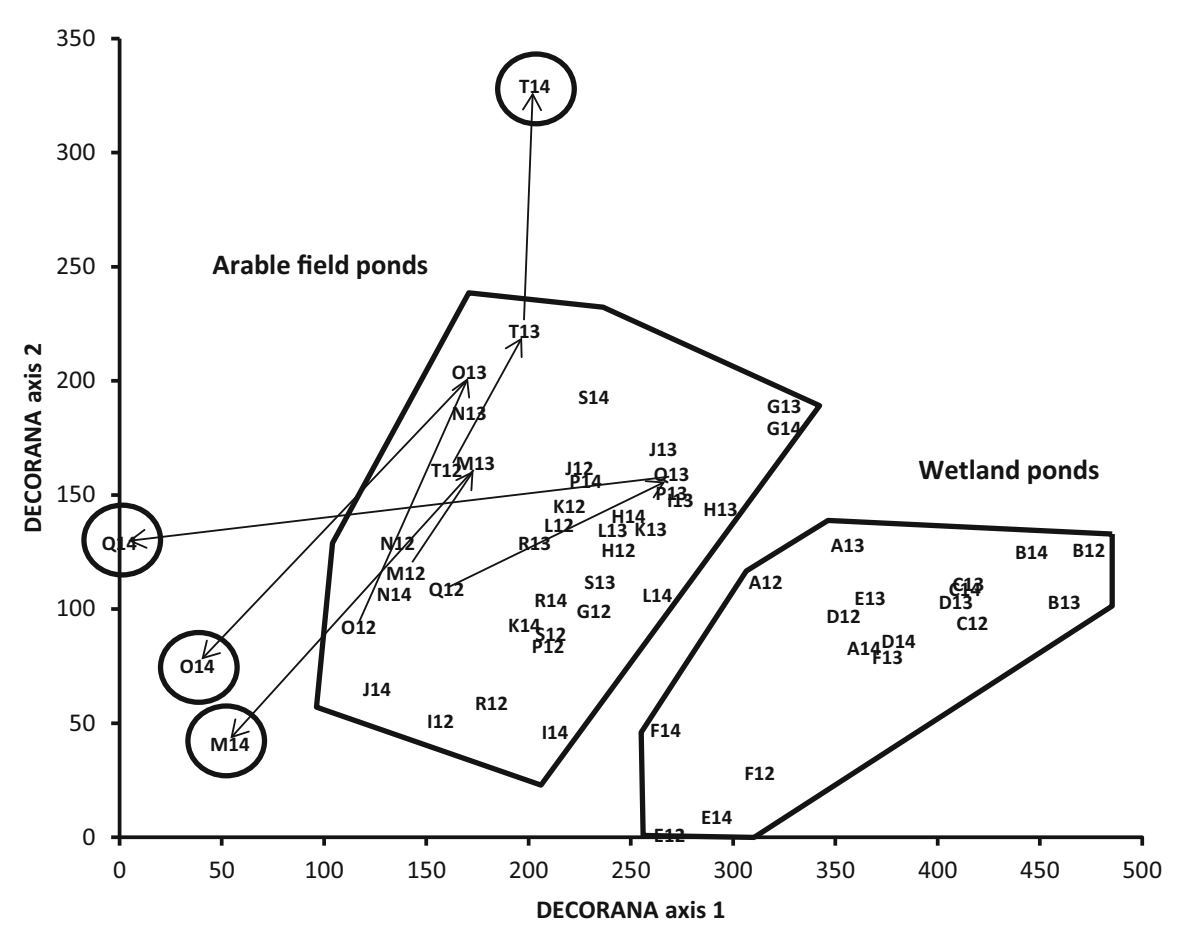

Fig. 8 DECORANA ordination of the plant communities from the 20 ponds surveyed in the summer of 2012, and re-surveyed in 2013 and 2014. The arable field or natural wetland ponds form two separate groups shown by the polygon outlines. Each pond is identified by a letter, $A-F$ for the 6 natural ponds, $G-T$ for the 14 arable field ponds. Within each group, the survey years are

explanatory variable for patterns and processes underpinning pond biodiversity. Area is often a weak predictor of pond invertebrate diversity, although stronger for plants (see Oertli et al., 2002). Area may be a weak predictor of invertebrate richness because variations to the area of a pond between years could result in historic effects from previous years carrying over into later years, which are not identified in subsequent snap-shot surveys when a pond may have a significantly different wetted area. Studies of temporary ponds often include some characterisation of previous drying, e.g. ponds that dry versus those that have not, or, better still, more precise measures of dry phase length and frequency e.g. Golladay et al. (1997), Wissinger et al. (1999), Della Bella et al. (2005) and Jeffries (2010) so that any impact of the history of the site is made obvious. The sustained impact of recent history on ponds invertebrates has also been shown for shade (weak effects on invertebrate communities, Mokany et al., 2008) and hydrology (plants, Jeffries, shown as $12=2012, \quad 13=2013$ or $14=2014$, e.g. $A 12=$ pond $\mathrm{A}$ in $2102, M 13=$ pond $\mathrm{M}$ in 2013 . The ponds with circles around their " 14 " position are all arable field ponds from 2014 when they were covered by cereal crop species and their individual trajectories from 2012 to 2014 are also shown by arrows

2008 and invertebrates Jeffries, 2010) but the impact of variations in wetted areas has not been systematically studied. The changing number and extent of inundated ponds echoes the scale dependent measures of pond numbers in Abedini et al.'s (2006) modelling audit. They suggested that, rather than an absolute estimate, it would be better to define how estimates of pond numbers changed with the scale of data resolution. For the Blakemoor Farm landscape there is no absolute number of ponds, but more of a varying range, characteristic of this landscape. It is likely that other landscapes will also have typical ranges which may be a better way to both define the ecology of the pond-scape and also identify how human impacts alter the functioning of the habitats if the annual and seasonal variation is markedly altered.

The number and area of the ponds were closely correlated with regional rainfall, but different pond types appear to be affected by rainfall over different time scales. Ponds in the natural wetland complexes 
and dune slacks were affected more by the rainfall during the previous 4-6 months, whilst those in pasture and arable fields responded to short term variation over the recent weeks. The numbers and areas of pasture and arable ponds, also varied proportionately more than in those of ponds in natural wetlands or dune slacks. This suggests that different pond types will vary in their susceptibility to climate change driven variations in rainfall in addition to the changes to the size distribution of the ponds.

The impact of climate extremes on the number and wetted areas of ponds was evident. The ponds in the pasture and arable fields were most numerous and extensive during the unusually wet summer and autumn of 2012. That year started with national concerns about drought but from the start of April unusually high overall rainfall including extreme individual events resulted in the wettest year on record in England, with concomitant economic losses and political fall-out (Jeffries, 2014). The extreme rainfall benefitted the Blakemoor ponds. This was not simply because they stayed wet (indeed unusually prolonged wet phases can be destructive to temporary pond biodiversity, Jones, 2013) but because the inundation prevented intensive agricultural use of the fields. Livestock was removed from the pasture because of the wet conditions preventing trampling, dunging and grazing which can degrade plant and animal communities (e.g. Schmutzer et al., 2008; Croel \& Kneitel, 2011). Vegetation was conspicuously tall and verdant in the summer when livestock were absent. In the arable fields the crops died in the flooded pools, creating the open, disturbed conditions for the specialist flora.

Whilst the numbers of ponds changed annually and seasonally the plant communities in the 20 ponds resurveyed between 2012 to 2014 did not show marked changes. There was little overall variation in communities between years, despite the return to drier weather after 2012, except for the ponds that were ploughed. Total numbers of taxa did not differ between the three years and nor did the coverage of dominant individual species in the natural wetland ponds. There were changes amongst the arable field pond species. These included the only species to be lost from the in the ponds after 2012, Shepherd'spurse, Capsella bursa-pastoris, which is a widespread generalist weed and therefore a surprising loss. The coverage of several other arable field species differed significantly between the three summers although there was no systematic trend of decline or gain. All species other than the Shepherd's-purse survived in the ponds, albeit often as scattered, short plants compared to the luxuriant swards of 2012. In contrast to 2012 the autumn of 2013 through into 2014 was relatively dry. The dried out arable field ponds were ploughed and cereal crops survived. By summer 2014 these potential pond sites were filled by crops and had lost their specialist flora. The extreme rainfall of 2012 benefitted the pond-scape, creating large numbers of wetted ponds and disrupting intensive farming which would otherwise homogenise the landuse. Intensification of land-use remains more of a threat to the ponds in this lowland agricultural landscape than climate variation, at least in the short term. This interplay of climate and land-use creates a complex challenge. A similar outcome was identified by Dolneger et al. (2014), in their case using modelling to predict changes in habitat availability for the Fire Bellied Toad, Bombina bombina, in Germany. Climate change scenarios led to an increase in suitable habitat, but only if land-use remained unchanged. It is more likely that the opportunities created for new crops and land-use intensification would destroy more habitat than the potential range expansion would allow.

In conclusion, 3 years of ground survey revealed a very high density of ponds, especially of smaller, temporary sites, and marked changes to their numbers and wetted areas between seasons and years driven by variations in regional rainfall. Ponds within different land-uses supported different plant communities, and each pond type contributed some unique communities and species to the overall site biodiversity. Ponds in different land-uses responded to rainfall over different time scales suggesting pond types may vary in sensitivity to climate change. Rainfall from an extreme climate event benefitted the pond-scape by inundating sites and disrupting intensive land-use. These results suggest that the threat to temperate ponds from climate change is likely to be a complex interplay between the actual variations to regional weather, the land-use in which a pond is situated and the type of pond.

Acknowledgments I am grateful to the owners of Blakemoor Farm for the permission to carry out this research and their interest in the work. This paper benefitted from the discussion 
with Dave Cooke, Peter Gilbert and Otaigbe Inegbedion and thoughtful suggestions from two anonymous referees and the editor.

Open Access This article is distributed under the terms of the Creative Commons Attribution 4.0 International License (http:// creativecommons.org/licenses/by/4.0/), which permits unrestricted use, distribution, and reproduction in any medium, provided you give appropriate credit to the original author(s) and the source, provide a link to the Creative Commons license, and indicate if changes were made.

\section{References}

Abedini, M. J., W. T. Dickinson \& R. P. Rudra, 2006. On depressional storages: the effect of DEM spatial resolution. Journal of Hydrology 318: 138-150.

Abinoza, A. \& K. L. Young, 2010. Sustainability of High Arctic ponds in a polar desert environment. Arctic 63: 67-84.

Action, P., 1993. National Pond Survey. Methods Booklet. Pond Action, Oxford.

Allende, L. \& G. Mataloni, 2013. Short term analysis of the phytoplankton structure and dynamics in two ponds with distinct trophic states from Cierva Point (maritime Antarctica). Polar Biology 36: 629-644.

Akponikpè, P. B. I., K. Wima, H. Yacouba \& A. Mermoud, 2011. Reuse of domestic wastewater treated in macrophyte ponds to irrigate tomato and eggplant in semi-arid West Africa: benefits and risks. Agricultural Water Management 98: 834-840.

Armitage, P. D., A. Hawczak \& J. H. Blackburn, 2012. Tyre track pools and puddles - Anthropogenic contributors to aquatic biodiversity. Limnologia 42: 254-263.

Baldwin, R. F. \& P. G. de Maynadier, 2009. Assessing threats to pool breeding amphibian habitat in an urbanizing landscape. Biological Conservation 142: 1628-1638.

Bosiacka, B. \& P. Pieńkowski, 2012. Do biogeographic parameters matter? Plant species richness and distribution of macrophytes in relation to area and isolation of ponds in NW Polish agricultural landscape. Hydrobiologia 689: 79-90.

Brooks, R. T., 2009. Potential impacts of global climate change on the hydrology and ecology of ephemeral freshwater systems of the forests of the northeastern United States. Climate Change 95: 469-483.

Brose, U., 2003. Bottom-up control of carabid beetle communities in early successional wetlands: mediated by vegetation structure or plant diversity? Oecologica 135: 407-413.

Calhoun, A. J. K., T. E. Walls, S. S. Stockwell \& M. McCollough, 2003. Evaluating vernal pools as a basis for conservation strategies: a Maine case study. Wetlands 23: 70-81.

Chou, W. W., S.-H. Lee \& C.-F. Wu, 2014. Evaluation of the preservation value and location of farm ponds in Yunlin County, Taiwan. International Journal of Environmental Resources and Public Health 11: 548-572.
Croel, R. C. \& J. M. Kneitel, 2011. Cattle waste reduced plant diversity in vernal pool mesocosms. Aquatic Botany 95: 140-145.

Davies, B., J. Biggs, P. Williams, M. Whitfield, P. Nicolet, D. Sear, S. Bray \& S. Maund, 2008. Comparative biodiversity of aquatic habitats in the European agricultural landscape. Agriculture, Ecosystems and Environment 125: 1-8.

Declerck, S., T. De Bie, D. Ercken, H. Hampel, S. Schrijvers, J. Van Wichelen, V. Gillard, R. Mandik, B. Losson, D. Bauwens, S. Keijers, W. Vyvermean, B. Goddeeis, L. De Meester, L. Brendonck \& K. Martens, 2006. Ecological characteristics of small farmland ponds: associations with land use practices at multiple spatial scales. Biological Conservation 131: 523-532.

Della Bella, V., M. Bazzanti \& F. Chiarotti, 2005. Macroinvertebrate diversity and conservation status of Mediterranean ponds in Italy: water permanence and mesohabitat influence. Aquatic Conservation: Marine and Freshwater Ecosystems 15: 583-600.

Dolneger, N., L. Freudenberger, N. Schneeweiss, P. L. Ibisch \& R. Tiedemann, 2014. Projecting current and potential future distribution of the Fire-bellied toad Bombina bombina under climate change in north-eastern Germany. Regional Environmental Change 14: 1063-1072.

Downing, J. A., Y. T. Prairie, J. J. Cole, C. M. Duarte, L. J. Tranvik, R. G. Striegl, W. H. McDowell, P. Kortelainen, N. F. Caraco \& J. M. Melack, 2006. The global abundance and size distribution of lakes, ponds, and impoundments. Limnology and Oceanography 51: 2388-2397.

Downing, J. A., 2010. Emerging global role of small lakes and ponds: little things mean a lot. Limnetica 29: 9-24.

Ewald, N., T. Kalettka \& L. Brendonck, 2012. Eyes of the landscape-value, conservation and management of European ponds. Limnologica 42: 251-253.

Fairchild, G. W., C. Robinson, A. S. Brainard \& G. W. Coutu, 2013. Historical changes in the distribution and abundance of constructed ponds in response to changing population density and land use. Landscape Research 38: 593-606.

Fasona, M. \& A. Omojola, 2009. Land cover change and land degradation in parts of the southwest coast of Nigeria. African Journal of Ecology 47: 30-38.

Gala, T. S. \& A. M. Meleese, 2012. Monitoring prairie wet area with an integrated LANDSAT ETM +, RADARSAT-1 SAR and ancillary data from LIDAR. Catena 95: 12-23.

Garcia-Gonzalez, C. \& E. Garcia-Vazquez, 2011. The value of traditional troughs as freshwater shelters for amphibian diversity. Aquatic conservation: Marine and Freshwater Ecosystems 21: 74-81.

Gibbs, J. P., 2000. Wetland loss and biodiversity conservation. Conservation Biology 14: 314-317.

Gilbert, P. J., S. Taylor, D. A. Cooke, M. Deary, M. Cooke \& M. J. Jeffries, 2014. Variations in sediment organic carbon among different types of small natural ponds along Druridge Bay, Northumberland, UK. Inland Waters 4: 57-64.

Golladay, S. W., B. W. Taylor \& B. J. Palik, 1997. Invertebrate communities of forested limesink wetlands in southwest Georgia, USA: habitat use and influence of extended inundation. Wetlands 17: 383-393.

Hartel, T. \& H. Von Wehrden, 2013. Farmed areas predict the distribution of amphibian ponds in a traditional rural landscape. PloS one. doi:10.1371/journal.pone.0063649. 
Hassall, C., 2014. The ecology and biodiversity of urban ponds. Wiley Interdisciplinary Reviews 1: 187-206.

Hassall, C., J. Hollinshead \& A. Hulla, 2012. Temporal dynamics of aquatic communities and implications for pond conservation. Biodiversity and Conservation 21: 829-852.

Heckenberger, M. J., C. J. Russell, J. R. Toney \& M. J. Schmidt, 2007. The legacy of cultural landscapes in the Brazilian Amazon: implications for biodiversity. Philosophical Transactions of the Royal Society B 362: 197-208.

Heino, J., R. Virkkala \& H. Toivonen, 2009. Climate change and freshwater biodiversity: detected patterns, future trends and adaptations in northern regions. Biological Reviews 84: $39-54$.

Jeffries, M. J., 2005. Small ponds and big landscapes: the challenge of invertebrate spatial and temporal dynamics for European pond Conservation. Aquatic Conservation: Marine and Freshwater Ecosystems 15: 541-547.

Jeffries, M. J., 2008. The spatial and temporal heterogeneity of macrophyte communities in thirty small, temporary ponds over a period of 10 years. Ecography 31: 765-775.

Jeffries, M. J., 2010. The temporal dynamics of temporary pond macroinvertebrate communities over a 10 -year period. Hydrobiologia 661: 391-405.

Jeffries, M. J., 2012. Ponds and the importance of their history: an audit of pond numbers, turnover and the relationship between the origin of the ponds and their contemporary plant communities in south-east Northumberland, UK. Hydrobiologia 689: 11-21.

Jeffries, M. J., 2014. Fear of water: floods, drought and the political threat to 20 years of conservation. Aquatic Conservation: Marine and Freshwater Ecosystems 23: $805-810$.

Johnson, W. C., S. E. Boettcher, K. A. Pioani \& G. Guntenspergen, 2004. Influence of weather extremes on the water levels of glaciated prairie wetlands. WETLANDS 24: 385-398.

Jones, I., 2013. The Impact of Extreme Events on Freshwater Ecosystems. British Ecological Society, London.

Jones, K., Y. Lanthier, P. Van Der Voet, E. Van Valkengoed, D. Taylor \& D. Fernández-Prieto, 2009. Monitoring and assessment of wetlands using Earth observation: the GlobWetland project. Journal of Environmental Management 90: 2154-2169.

Lake, P. S., 2011. Drought and Aquatic Systems. Effects and Responses. Wiley, Chichester.

Lansdown, R.V., 2009. A field Guide to the Riverine Plants of Britain and Ireland. Including selected Vascular Plants, Bryophytes, lichens and Algae. Ardeola Environmental Services, Stroud.

Lehner, B. \& P. Döll, 2004. Development and validation of a global data base of lakes, reservoirs and wetlands. Journal of Hydrology 296: 1-22.

Lott, D., 2001. Ground beetles and rove beetles associated with temporary ponds in England. Freshwater Forum 17: 40-53.

Lukás, B. A., G. Sramkó \& A. V. Molnár, 2013. Plant diversity and conservation value of continental temporary pools. Biological Conservation 158: 393-400.

Lunn, A., 2004. Northumberland. Harper Collins, London.

Oertli, B., D. A. Joye, E. Castella, R. Juge, D. Cambin \& J.-B. Lachavanne, 2002. Does size matter? The relationship between pond area and biodiversity. Biological Conservation 104: 59-70.

Met Office, 2015. http://www.metoffice.gov.uk/climate/uk/ interesting (accessed 22/03/2015).

Mokany, A., J. T. Wood \& S. A. Cunningham, 2008. Effect of shade and shading history on species abundances and ecosystem processes in temporary ponds. Freshwater Biology 53: 1917-1928.

Mozley, A., 1944. Temporary ponds, a neglected natural resource. Nature 144: 490.

Pitt, A. L., R. F. Baldwin, D. J. Lipscomb, B. L. Brown, J. E. Hawley, C. M. Allard-Keese \& P. B. Leonard, 2012. The missing wetlands: using local ecological knowledge to find cryptic ecosystems. Biodiversity and Conservation 21: 51-63.

Rodwell, J. S. (ed.), 1992. British Plant Communities, Vol. 3., Grasslands and Montane Communities Cambridge University Press, Cambridge.

Rodwell, J. S. (ed.), 1995. British Plant Communities, Vol. 4., Aquatic Communities, Swamp and Tall Herb Fens Cambridge University Press, Cambridge.

Rodwell, J. S. (ed.), 2000. British Plant Communities, Vol. 5., Maritime Communities and Vegetation of Open Habitats Cambridge University Press, Cambridge.

Rosset, V. \& B. Oertli, 2011. Freshwater biodiversity under climate warming pressure: identifying the winners and losers in temperate standing waterbodies. Biological Conservation 144: 2311-2319.

Rosset, V., A. Lehmann \& B. Oertli, 2010. Warmer and richer? Predicting the impact of climate warming on species richness in small temperate water bodies. Global Change Biology 16: 2376-2387.

Schmutzer, A. C., M. J. Gary, C. B. Burton \& D. L. Miller, 2008. Impacts of cattle on amphibian larvae and the aquatic environment. Freshwater Biology 53: 2613-2625.

Seekell, D. A. \& M. L. Pace, 2011. Does the pareto distribution adequately describe the size-distribution of lake? Limnology and Oceanography 56: 350-356.

Soti, V., C. Puech, D. Lo Seen, A. Bertran, C. Vignolles, B. Monder, N. Dessay \& A. Tran, 2010. The potential for remote sensing and hydrologic modelling to assess the spatio-temporal dynamics of ponds in the Ferlo Region (Senengal). Hydrology and Earth System Sciences 14: 1449-1464.

Stace, C. A., 1997. New Flora of the British Isles. Cambridge University Press, Cambridge.

Thiere, G., S. Milenkovski, P.-E. Lindgren, G. Sahlén, O. Berglund \& S. E. B. Weisner, 2009. Wetland creation in agricultural landscapes: biodiversity benefits on local and regional scales. Biological Conservation 142: 964-973.

Usio, N., M. Imada, M. Nakagawa, A. Munemitsu \& T. N. Akamura, 2013. Effects of pond draining on biodiversity and water quality of farm ponds. Conservation Biology 27: 1429-1438.

Verpoorter, C., T. Kutser, D. A. Seekell \& L. J. Tranvik, 2014. A global inventory of lakes based on high-resolution satellite imagery. Geophysical Research Letters 41: 6396-6402.

Wassens, S., A. Walcott, A. Wilson \& R. Friere, 2013. Frog breeding in rain-fed wetlands after a period of severe drought: implications for predicting the impacts of climate change. Hydrobiologia 708: 69-80. 
Williams, D. D., 1987. The Ecology of Temporary Waters. Croom Helm, London.

Williams, P., M. Whitfield, J. Biggs, S. Bray, G. Fox, P. Nicolet \& D. Sear, 2003. Comparative biodiversity of rivers, streams, ditches and ponds in an agricultural landscape in southern England. Biological Conservation 115: 329-341.

Williams, P., M. Whitfield \& J. Biggs, 2008. How can we make new ponds more biodiverse? A case study monitored over 7 years. Hydrobiologia 597: 137-148.

Williams, P., J. Biggs, A. Crowe, J. Murphy, P. Nicolet, A. Weatherby A. \& M. Dunbar, 2010. Countryside Survey:
Ponds Report from 2007. Technical report No 7/07. Pond Conservation and NERC/Centre for Ecology and Hydrology. Lancaster Environment Centre, Lancaster

Wissinger, S. A., J. Bohonak, H. W. Whiteman \& W. S. Brown, 1999. Subalpine wetlands in Colorado: habitat permanence, salamander predation and invertebrate communities. In Batzer, D. P., R. B. Radar \& S. A. Wissinger (eds), Invertebrates in Freshwater Wetlands of North America. Wiley, New York.

Wood, P. J., M. T. Greenwood \& M. D. Agnew, 2003. Pond biodiversity and habitat loss in the UK. Area 35: 206-216. 